\title{
КАТЕГОРІЯ «СМЕРТЬ» У ТЕКСТОВОМУ КОНЦЕПТІ НОВЕЛ М. ХВИЛЬОВОГО
}

Свірська Ж. М. Категорія «смерть» у текстовому концепті новел М. Хвильового.

У статті послідовно розгортаються трагічні мотиви перебудови світу за жорстокими правилами, до яких людина виявляється не готовою. Шляхом аналізу й зіставлення текстових концептів новел М.Хвильового окреслено реакції персонажів на почуття «зайвості» в пореволюційні часи XX століття. У дослідженні акцентується на вагомих складниках екзистенційної суперечності між прагненням до самореалізації та відсутністю перспектив. Виокремлено проблематику новел: за втрат упевненості у світлому майбутті настроєва чи подієва смерть - невідворотний результат.

Ключові слова: концепт «смерть», «конфліктогенний» соціальний статус, екзистенційний вибір, психологічна напруга, депресія.

Свирская Ж. Н. Категория «смерть» в текстовом концепте новел Н. Хвилевого.

Статья посвящена художественному анализу новел Н. Хвилевого. Автор, наделяя центральных персонажей конфликтным социальным статусом, обращает внимание на составные экзистенциального выбора между стремлением к самореализации и отсутствием перспектив. В статье выделена проблематика: без 
уверенности в светлом будущем разочарование, депрессия или смерть - неизбежный результат.

Ключевые слова: концепт «смерть», конфликтный социальный статус, экзистенциальный выбор, депрессия.

Svirs'ka Z. M. The category of "death" in a text concept of M. Khvylovyy's novels.

Artistic thanatology becomes the new research field of contemporary literature. Thanatological motives of M. Khvylovyy's creative concept left unattended by scientists, which is an obstacle to comprehension of the writer's individual style.

The article adherently shows a tragic motive of the world brutal restructuring, to the rules of which the person is not ready. The text selection caused by a distinct psychology of the characters, which is manifested through the constant "death". Author puts characters in the same conditions: the loss of ideological illusions committed in frustration, a sense of superficial things in the "winners festival", the constant environmental pressure. The main characters of stories exist in non-existent world of revolution, which is the "Dreamland" and the "country of explosions" at the same time. The central characters are endowed with "conflict" social status. In the early 20 s they faced with frustration and depression due to the inability to find usability of their potential. The study focused on the important components of existential conflict between the desire for self-fulfillment and the lack of prospects. And then - psychological tension, depression, passionate looking into death.

Psychoanalytic interpretation is chosen for studying the concept of "death" in the individual style of the artist, the artistic structure of the stories especially. Special attention is paid to the stylistic originality of M. Khvylovyy's prose. Spiritual-value orientation of characters were found while analyzing and comparing stories. Author outlines causes and consequences of the collapse of ideals and awaited reaction to the feeling of «superficial things» in post-revolutionary times. First, singled out problems: the emotional or eventual death is the inevitable result of losing the confidence of the bright future.

Key words: "conflict-" social status and existential contradiction.

Художня танатологія - нова сфера досліджень сучасного українського літературознавства. Аналіз наукових розвідок засвідчує, що ця важлива антропологічна та культурологічна проблема вивчалася 3 різних кутів. У розвідках історико-літературного характеру простежувалося семантичне наповнення мотиву смерті, функціонування танатологічних елементів у художньому тексті. Ю. Лотман застосовував структурний метод, шлях інтуїтивістів обирав В. Топоров, М. Бахтін - наратологічний.

Микола Хвильовий одним із перших в українській літературі періоду державотворення суб'єктивно й пристрасно почав осмислювати проблему смерті. Знецінення вартості життя у XX столітті пов'язано 3 репресивними механізмами. Засновник течії активного романтизму передчасно пішов у засвіти на сороковому році. 
Безумовно, нині маємо розлогу палітру літературознавчих інтерпретацій прози М. Хвильового. Науковці аналізували парадигму невротичного героя в наративі повістей, дотичні гендерні аспекти творчої концепції. Численними $є$ статті, де приділено увагу дисгармонійному як аксіологічній складовій поетики митця, експресіоністичним тенденціям творів [1; 3; 5; 9].

Грунтовно висвітлює психопатичний дискурс Миколи Хвильового С. Павличко, яка зазначає: «він пережив світоглядну кризу, яка поставила його на межу постійного душевного зриву. Неврастенія, душевна криза, психічна хвороба, ненормальність, істерія - цими словами визначаються лейтмотиви його прози» $[6$, c. 266]. Однак поза увагою залишаються танатологічні мотиви новел, що є перепоною на шляху до осягнення стильової своєрідності письменника. Вибір текстів зумовлений яскраво вираженою психологією персонажів Миколи Хвильового, що проявляється через константу «смерть».

Мета статті: через аналіз і зіставлення текстових концептів новел «Юрко» та «Заулок» окреслити причини й наслідки краху омріяних ідеалів та реакцію персонажів на почуття «зайвості» в пореволюційні часи.

Як основний метод варто обрати історико-літературний, щодо вивчення феномена «смерть» в індивідуальному стилі митця, зосібна в художній структурі новел застосуємо психоаналітичну інтерпретацію. Для тлумачення текстів орієнтуємося на концепцію М. Моклиці, яка в монографії «Модернізм як структура: Філософія. Психологія. Поетика» розглянула естетику модерну на основі психологічних типів К. Юнга [4].

Початок XX століття став переламним періодом як у суспільстві, так і в розвитку літератури, що пориває з традицією та шукає шляхи відображення дійсності. Результатом пошуку стають новий тип людини у новій системі соціальних відносин, нові моделі стосунків. Цю тезу вповні ілюструє творчість М. Хвильового, який писав: «Я вірю в «загірню комуну», вірю так божевільно, що можна вмерти» [7, с. 113]. Природно, що через його новели наскрізне проходить концепт «смерть».

Письменник, який руйнує усталені класичні варіанти, послідовно розгортає трагічний мотив перебудови світу за () Ж. М. Свірська, 2016. 
жорстокими правилами, до яких людина виявляється не готовою. Автор уміщує персонажів у однакові умови: втрати ідеологічних ілюзій, розчарованості у здійсненому, сталого тиску оточення. А відтак - депресія, пристрасне видивляння у смерть.

Герої новел «Юрко», «Заулок» знають, що минуле залишилося в минулому - «назад нема вороття» [7, с. 169]. Треба зробити вибір: або, або («дух творчості, дух руйнування)» [7, с. 169]. На грунті духовного вакууму виникає відчуття абсолютної зайвості на «святі переможців», викликане відірваністю від життя. Психологічна напруга підсилюються спогадами про часи, коли чекісти вершили долі інших, стояли 3 тим, хто знав прагнення мільйонів. Слід обирати: змиритися чи піти 3 життя. Змиритися - означає для революціонерів відмову від ідей, мрій, того, за що вмирали, убивали, чому присвятили себе і чого ніколи не буде у збудованому суспільстві.

Юрко, із однойменної новели, після громадянської війни потрапляє на Донеччину - «в завод» [7, с. 169]. За згадками про Перекоп зрозуміло, що йдеться про 20-й рік. Після революції, коли, здавалося, пройде певний відтинок часу й народжені в битвах омріяні ідеали гармонійної світобудови втіляться в реальність, настала «стадія організації». Життя поділилося на «тепер» і «тоді».

У наративі твору важливо те, що Юрко був не лише причетним до революційних подій. Саме революція спровокувала глобальність його інтересів: «гори Юри (Швайцарія), юрта, за юртою тайга» [7, с. 169]. Тавтологія «молодість молода» виявляє граничну тугу за часом, коли «юні дзвони юність молоду дзвонили». Залізо «співає», молотки «верещзать» - звуки закликають до пам'яті «тихі спогади у гострих лезах тонкого упаду». Без революції, «коли нема творчості, життя тече нудно, одноманітно» [7, с. 170]. Тепер для Юрка пересипаються у кошику часу дні, тижні: «холодні й теплі, близькі, далекі... [7, с. 170]. У новелі принаймні кілька разів виникає характеристика «довгих днів цілого року» [7, с. 169]. Письменник поступово вибудовує ланцюжки подій через низку асоціацій, що виступають головним засобом формування сенсу життя: «Тече життєва ріка одноманітно». Навколо «...nрисмерк, будні, зажури, як до революиїі» [7, с. 169]. Гостро відчутна мотивна тенденція катастрофізму: «тоскно дивитись на степ, де мріє далина» [7, с. 169]. Романтичний, запальний молодий чоловік бачить перед собою тільки 
темряву («Що думає ніч?» [7, с. 169]). Він постійно «думає», а осмисливши події останніх років, жахається. У романтика світлої комуни майбутнього завжди «нудить niд сериее» [7, с. 176].

Юрко, який опинився на маргінесі поза товариством «бойовим» i мирним, безнадійно споглядає життя. Експресивні припущення: «рипустім, < ..> Я завідував би райрибою. Ти розумієи - райрибою! А може, райсіллю? Хa!» [7, с. 177] підкреслюють безперспективність майбутнього. Герой новели - ні живий, ні мертвий. Він кляне завод, не сприймає потреби щоденної праці, яка не приносить втіхи: «A на заводі я теж не можу - тут треба марудної праці, а я не можу... а завідувати райрибою я теж не можу» [7, с. 177].

М. Хвильовий 3'ясовує вагомий аспект мотиву зникнення інтелігенції, грунтований на оцінці пролетаріату. Юрка ображають обмежена відвертість робітника - «чоловіка темного, який досі не добрав щзо до чого» [7, с. 169]. Про пролетаріат йдеться недарма, у цій фразі зосереджено кілька важливих інформаційних вузлів. До структури новели введено «текст у тексті», де постає переживання трагізму, породженого наслідками революції. «Клянуся, щзо комуніст» [7, с. 177], константа поведінки героя, його провідна риса. Проте комітетчики називають Юрка «гість» [7, с. 173], до «справжніх представників пролетаріату» [7, с. 173] заводські робітники зараховують себе. А «nопутчик», - це підозріло-ненадійний прошарок, що його слід скеровувати, перевиховувати («не так лекиії читає») [7, с. 172].

Звісно, гасло пролетаріату - «Моя власть, $і$ баста!» [7, с. 174]. Це той гегемон, що «плює на всіх $i$ вся» [7, с. 174]. Юрко «на сподi душі» їх саркастично характеризує: «таранкуваті, мамулуваті», «типічні сурйози» [7, с. 173]. Наступна поява в семантичному світі новели «залізного, кам'яного» - «ми» виводить мотив крізь призму авторського сарказму у ширший контекст. «Mи - король землі»! Пафосна лінія пройнята іронією: «Отче наш, електричної системи віку, да буде твоя непохитна воля там - на землі, як тут - у заводі» [7, с. 174]. Розрив між ідеями та реальністю нестерпний, песимізм посилюються тим, що новоявленого «всі» нахабно висміюють. «Попутчик... так...» - стає однією 3 найбільших трагедій, які доводиться переживати («Юрко спалахував») [7, с. 174].

Які ще причини позбавляють його душевної рівноваги? Епізод, що пов'язується 3 окремими деталями настроєвого, подієвого або () Ж. М. Свірська, 2016. 
ідеологічного кодів новели, прояснює моральні пріоритети героя новели. Пиятика - нормальне явище («діло заводське» [7, с. 178]). У ячейці «уламують» випити «всі». Голова фабзавкому недарма «примружує око»: «справді, чи не випити?» [7, с. 172]. I секретар під'юджує: «Пий, та не пропивай розуму», і Наталка ущипливо ганить: «Та щуо це ви, Юрко! Невже ми в чернищі приписалися?» [7, с. 173]. Читачеві зрозуміло, чому переконаний «комуніст» їх цурається. Цілісний більшовик не п’є, та йому не вірять: «хіба таки Троцький не n'є?» [7, с. 173]. Упадає в око, що товариші комуністи п'ють небагато, бо «більи не було» [7, с. 173].

Революційні завоювання деградують. Ваговита невідповідність між «учора» й «сьогодні» - у прямолінійних аргументах робітника, позаяк недоумкуватий Остап: «вип'є пляшку, то й за власть совітів. Більшовиків подавай... більшовицьку власть, а то й у саму ком'ячейку записуй» [7, с. 173]. Остап «і сьогодні випив» [7, с. 178], і «Наталка пила» [7, с. 176]. Ця дисгармонія - причина душевних мук і життєвої драми. Згодом бунтар проти всього, що не вкладалося в його розуміння ідеального образу революції лише здвигає плечі. Так маркується мотив розчарування. «Божевільна віра» мала стати основою романтизму революції (романтики вітаїзму), яка допомогла б перемогти іiі ж таки трагізм і розчарування», - уважає С. Павличко [6, c. 267].

У «сонному посьолку» - «багато» людей («багато творять, багато - так») [7, с. 170]. Він намагається тверезо оцінювати сучасність: «люди однакові, люди різні» [7, с. 169]. Чоловік розуміє: «Люди - не воли», та спосіб їх життя для нього примітивний. Інтереси людей «в завод $i$ - $i$ за заводом» видаються йому дріб'язковими: «Улаштовували вистави - (заводська молодь у футбол $і$ лявн-теніс грає)» [7, с. 171]. «Нові люди» та культура «як до революuіï» - речі несумісні. Дратує музика на міщанський мотив, гнітить, що «знову був трактир», - направду химерно «сьогоднішнє» єднається із позавчорашнім.

Свідок епохальних подій недавнього минулого не виносить тиші: «досі почуваю гармати, досі бачу барикади» [7, с. 177]. Персонаж під впливом стресу виявляє патологічні риси, схиляється до немотивованого радикалізму: "Я родився для вибухів...», "Я ладен робити замах хоч на самого Пуанкаре» [7, с. 177]. Відсутність 
чутливості до смерті спричиняє появу думок про унікальність та обираність («за кордон революиію робити» [7, с. 169]). Найтрагічніше те, що у спотвореній свідомості відбулося жаске зрощення: «дух руйнування〉 - життя, праця - символ духовної смерті.

Для людини, що тривалий час перебувала у світі екзистенційної катастрофи, майже не залишалося шансів на порятунок. Зрештою, «Яконцепція» героя твору руйнується. Звернімо увагу, що власне на «Я...» обривається лист. Першою реакцією цього процесу була апатія: «лягав не роздягаючись, «не вмивався, «гуляти» «не ходив», на танцях «позіхав» [7, с. 174]. Наступна - «тиха лютість» [7, с. 174] - не натяк на душевні муки героя. Це пряме формування мотиву смерті після того, як прекрасна ідея обернулася чорною реальністю.

Юрко, незважаючи на безліч підкреслених «я не можу» - «я не винесу», ще не думає про суїцид. «Звичайнісінька людина», розуміючи слушність фрази «людина, хоч $i$ комуніст», відчайдушно шукає соломинку, щоб ухопитися. Герой новели «уперто думає про жінку», яка «одчинить двері, трішки заспана, теплий жіночий дух від неї... $i$, як у молоденької дівчини, зітхання» [7, с. 170].

Водночас Наталка, - «не пишна женщина», як Мар'яна, чи красуня Б'янка, чи Вівдя, яка «дуже гарна з себе». У Наталки «ноги трішки колесом» $[7$, с. 170]. На передній план виходить далеко не зовнішність, а те, що надає сенсу життю. Згадаймо зізнання М. Фітільова у «Вступній новелі»: «Я до безумства люблю ніжних женщин $з$ добрими, розумними очима» [7, с. 113]. Жінка - «дивиться синьо», так «дивляться не всі», так «буває не часто» [7, с. 170]. Зазначимо, що дослідники чимало уваги приділили функціональним особливостям епітету «синій», - улюбленого тропу митця.

Показово, що Наталка першою розпочинає закохувати в себе. Простежимо вибір вербальних та невербальних засобів, що сприяють реалізації інтрижки: «бере за руку»; зустрічає «в одній сорочц̧і» [7, с. 170]; увійшла в Юркову кімнату «білою плямою»; «сиділа поруч Юрка»; «ї̈ тіло торкалось його тіла»; «підставляє...дзеркало». «Гарний? <..> Гарно? <..> Гарно. <..> Гарно? [7, с. 170]. Урешті $€$ порятунок для пошматованої душі: «йому було гарно» [7, с. 170].

Здатність до вбивства вимагає потенційних можливостей, особливої сили волі. Натомість людина, наділена величезною енергією, не наважується «зачепити» жінку, у якої «горіли очі», 3

() Ж. М. Свірська, 2016. 
обличчям «світлим, як винне повітря восени - ранньої» [7, с. 173]. Чоловік, який «родився для вибухів», втратив мужність. Виявляється, «просто сказати - зовсім не просто» [7, с. 174].

I хоч манить млосне бажання володіти («Він сів біля неї» [7, с. 175]), чоловік діє продумано: «подумав $i$ взяв іï за руку» [7, с. 175]. Попри недвозначний натяк («вона знизила вї̈»), - він урешті-решт зметикував: «і йому забилось серие» [7, с. 175].

Кульмінація в новелі маркується: «були останні дні червня, запашні... I прийшла неділя» [7, с. 176]. Семантична роль епізоду на леваді Торця начебто зрозуміла. Жінка активно зваблює чоловіка: «надто весела, сміялась», «стан їи манливо колихався», «раз у раз голосно скрикувала», «з реготом розказувала» [7, с. 176] про кумедний випадок, набиваючи собі ціну. Збуджена Наталка уміло кокетує, начебто «уважно розглядає кущ осоки» [7, с. 176].

Елегійно-мінорний опис мовчазного поля постає в одній площині з настроєм, що веде до легкого смутку. Однак «сонще мжить золото на ріку», - чутливість загострюється. Юрко сідає біля Наталки, пригортає іiі. Оповідь чимдалі інтимізується: він «узяв за талію» <..> «поцілував їй шию» [7, с. 176]. Кожна дія чоловіка коментується автором: «Вона не говорила». За переконанням Сімони де Бовуар, «мовчання - подоба спільництва: воно висловлює згоду, надто глибоку для слів» [2, с. 234] Усупереч сподіванням молодої жінки, обранця не вдалося намовити на близькість, вони «сиділи цілу годину так» [7, с. 177].

Зрештою з'являється «широке поле», і «все було видно» [7, с. 177]. Аскетичний Юрко вкотре «думає» («думав ї схилити на землю») [7, с. 177]. Жінка упевнена у своїй перемозі, однак чоловік поспіхом підвівся. Знову на позначення загибелі з'являється образ ночі. Примара «синьої тіні», що фігурує на початку новели, не $є$ семантичною константою, вона стає репрезентантом трагічного мотиву. Винятково цікавим є питання: чому чоловік відмовляється від статевих стосунків із жінкою, яка «дивиться синьо»?

Зневажена Наталка, хоч і дивується невідповідності щодо очікуваного, поводить себе раціонально виважено. Спершу ані найменшим жестом не виявляє розчарованості, згодом «зажурено» говорить про емісію-девальвацію. А щойно Остап пішов, «одразу захропла» [7, с. 178]. 
Заміжня жінка мала б розуміти, що, загорнувши сніданок іншому, дає тому сподівання на взаємність, надійну підтримку. Сімона де Бовуар підкреслювала: «Шлюб - це єдина можливість забезпечити своє існування, єдине виправдання власного покликання на землі. Суспільство зобов'язує жінок брати шлюб, аби вони змогли виконати дві функції, перша 3 яких - дітонародження. I, отже, друга функція жінки - це вдоволення сексуальних потреб чоловіка і турбота про його домашнє вогнище» [2, с. 8].

В аналізі кризового стану Юрко доходить до розуміння, що його зможе врятувати сім'я. Автор натякає на два можливі варіанти, які, врешті, об'єднуються в один. Кохана зблідла», вже ось «сіла на ліжко», поруч - чоловік. Він стривожено-розсудливо, 3 надією уточнює у жінки, яка його домагалась: «Я вам, як товариш, як...» [7, с. 178]. Урешті 3'ясовується каузальний аспект проблеми: спустошений невротичний чоловік хоче жіночого тіла лише за умови сердечної приязні. «Вона подивилась на Юрка - йому горіли очі, і їй спалахнули очі» [7, с. 178].

В українців тілесна насолода має специфічну рису кордоцентризм. Юрко не прагне тваринного лібідо, він прагне, щоб жінка належала йому думками, недарма міцно обняв «ї̈ голову» [7, с. 178].

Найбільш емоційним $є$ епізод, коли Юрко наважується: «Наталю! - і голос йому затремтів <...> [7, с. 178]. М. Хвильовий не повідомляе, що промовив чоловік. Мабуть, прозвучало найприродніше освідчення, щемке визнання про муки нереалізованих почуттів. Із розпуки, відчаю, з безнадії та безвиході народжуються лише щирі слова, що мають сакральне значення. Однак у посьолку було тихо» [7, с. 178]. Це зависла тиша-смерть, що перетворює слова на примару.

Тишу в кімнаті порушує відгомін дитячих голосів, що долинає 3 вулиць: «тільки діти кричали» [7, с. 178]. Художня логіка веде до підтексту про побачену та окреслену життєву перспективу одруження, про одвічні вартості, без яких не може існувати, розвиватися суспільство, які відкидалися революцією, нівелювалися. Панує настанова на шлюб як на договір між індивідуумами, грунтований лише на вільному волевиявленні. Наступний діалог переконливо свідчить про події соціальної історії України першої чверті

() Ж. М. Свірська, 2016. 
XX століття. Читача не дивує відмова молодої жінки від звичайного людського щастя. «Вона тихо говорила: У мене не було дітей... Що ви кажете?.. Я не хочу... <..> Що ви кажете?.... Не хочу... [7, с. 178]. У перехідну добу шлюб перестав бути цінністю, позаяк на повсякдень не забезпечує ні вірою, ні захистом. У новелі остаточно окреслюється мотив зникнення - Юрко приречений на життєву поразку.

Жанр твору дає змогу не вдаватися до маскування особи автора, тому його «Я» у структурі новели є цілком логічним («I $я \kappa$ ви думаєте, чи не час мені плюнути й почати нову новелу? Час, певно, час») [7, с. 178]. Нам імпонує думка С. Павличко: «Хвильовий часто ділиться з читачем своїми думками про власний текст, грається 3 ним. $<\ldots>$ У такому стилі письма сюжетна послідовність і завершеність тексту чи класична виписаність характеру героя не мають сенсу» [6, c. 268].

Автор робить останнє зусилля, проте остаточну крапку не ставить. Неодмінною ознакою фіналу вибудуваних подій має стати життєва драма. Грань мотиву руйнації матеріалізується через звукові образи пожежі на заводі, нічної тривоги: «гули гудки», «хтось закричав на вулиці» [7, с. 177]. Конкретною ознакою атрибуту смерті $\epsilon$ художня деталь «стальна хрестовина» [7, с. 179]. Ця антитеза життю образно демонструє, що примирення з життям означає небуття.

У психології чекістів укорінюється мізантропія. I Юрко, і Мар'яна, не порозумівшись із оточенням, гризоти, що їх точать, пристрасно виливають «товаришам». Схвильований Юрко «довго, надхненно» пише невідомому нам адресату. Адресат Мар'яни на «Сєвєре» [7, с. 325]. «Мильий друг» із далекого «російського» минулого не відчує «грусти», він не підтримає сьогодні. Попри те, що монологів здебільше не розуміють, їм нікому це сказати - вони чужі серед своїх близьких. Істеричне «не можу»: «жити», «боротися», «змиритися», «нічого змінити», - є свідченням психічної деградації.

Герої новел «Юрко» і «Заулок» жалкують за жагою до боїв, до вибухів, до вбивств. Жаскі зрощення тривоги та лиходійства, крові та смерті стають невід'ємними складовими самозречених «муралів» революції. С. Павличко вважала: «у випадку Хвильового маємо справу 3 «божевільною вірою», від якої можна вмерти» [6, с. 267].

M. Хвильовий натиснув на больові точки як своєї так i сьогоднішньої епохи. Художня інтерпретація мотиву смерті 
реалізується автором у модель світобудови, провідною ознакою якої $\epsilon$

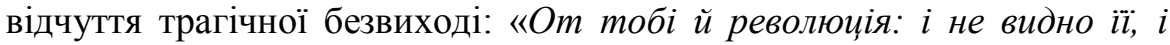
видно ї̈. Як ота благодать з неба: щзось, десь, а в руки не візьмеш...» [7, с. 171]. Загроза потрапити під вплив агітаційних міфів для втілення примарного «царства справедливості» нависає повсякчас. Сучасне суспільство характеризується ослабленим переживанням смерті, а символи насильства та індустрія образів знищення людини спотворюють свідомість покоління перших десятиліть XXI ст. Відкрити дорогу насильству може неусвідомлена «манія величі». У підтексті новел наявний футуристичний прогноз - «як почнеш шукати правди, то, гляди, $i$ залізеш у кривду» [7, с. 169]. Імовірно, для багатьох чоловіків і жінок подальший перехід від руйнівної діяльності до щоденної праці стане глухим кутом.

\section{Література}

1. Агеєва В. «Зайві люди» у прозі М. Хвильового / В. Агеєва // Слово і час. 1990. - № 10. - C. 3-9. $390 \mathrm{c}$.

2. Бовуар Сімона де. Друга стать / Сімона де Бовуар. - Т. 1. - К. : Основи, 1994. -

3. Жадан С. Хроніка ідеального самогубства : [до 70-річчя 3 дня загибелі М.Хвильового] / С. Жадан // Столичные новости. - 2003. - № 17 (13-19 мая).

4. Моклиця М. В. Модернізм як структура: Філософія. Психологія. Поетика : [монографія] / М. В. Моклиця. - [2-е вид., доповн. і переробл.]. - Луцьк : РВВ «Вежа», 2002. $-389 \mathrm{c}$.

5. Немченко І. Ю. Герой в пошуках сенсу життя чи смерті? (на матеріалі новел М. Хвильового) / І. Ю. Немченко // Діалог душ : зб. наук. ст. за матеріалами конф., присвяч. пам'яті проф. В. В. Фащенка. - Одеса, 2001. - С. 95-101.

6. Павличко С. Д. Психопатичний дискурс : Микола Хвильовий / С. Д. Павличко // Теорія літератури. - К. : Основи, 2002. -679 с.

7. Хвильовий М. Твори : у 5-и т. / [упоряд. і загал. ред. : Г. Костюк] - НьюЙорк ; Балтимор ; Торонто : Смолоскип, 1978-1986. - Т. 1 : [передм. Г. Костюка]. 1978. -437 c.

8. Юнг К. Г. Об отношении аналитической психологии к поэтикохудожественному творчеству / К. Г. Юнг // Зарубежная эстетика и теория литературы ХІХ - ХХ вв. - М., 1986. -547 с.

9. Ямчук П. М. Екзистенціальна проблематика імпресіоністичної новелістики Миколи Хвильового / П. М. Ямчук // Історико-літературний журнал - 1996. - № 2. C. $47-50$.

Стаття надійшла до редакиії 08.11.2015 p.

() Ж. М. Свірська, 2016. 